found that we obtain a greater reproduction of new bone when the haversian canals are well opened up by roughening the bone with the chisel, it necessarily follows that we shall secure greater circumferential reproduction if no part of the transplant is covered by an impervious membrane.

I would suggest that there may be a small sequestrum thrown off from the transplant in Dr. Wetherill's case, which lappened in a case of ours two yenrs ago in which there was a slight latent infection. The sequestrum constituted about one-fourth of the original graft, the other three-fourths having liealed in and reproduced a considerable amount of bone.

W. T. Brown, M.J., El l'uso, Tex.

\section{Evidences of Arsenical Poisoning}

To the Editor:-In an editorial on this subject in Tins Joumsa, Mny 31, 1913, p. 1710, it is stated that "by no oriinary measures, sueh as those to which criminals would be likely to resort, could arsenic be introduced into the boly after denth and be carried by the ordinnry processes of difiusion to " point [the brain] so remote from the echtral portions of the body."

This is so at variance with established facts that I wish to clirect your attention to the matter in the interest of medical jurisprudenee.

It is true, as the editorial points ont, that formerly the belief was entertained that if arsenic is found in the brain of a cadaver, the poison must have been introduced into the body before deatl. During the past thirty years, however, many experiments on the dead bodies of man and of the lower animals have abmundy established the fact that this view is entirely untenable. The record of these experiments is found in easily accessible literature.

Vaughan in 1883 took up the subject and beeame the pioneer investigator. With an ordinary syringe, he injected arsenic into a cadaver by the month and the rectum. The borly was put nside for twenty-five days; then the brain was removed and submitted to chemienl analysis; in a little more than a thousnul grams of it he found $3.63 \mathrm{mg}$. of arsenic, calculated as the trioxid. In 1888 Witthaus continued the investigntion. He first used three corlnvers, and into two of them he injected arssuic through the month; in the third the arsenic was injected into the stomach and abdominal cavity. Fourteen days later the brains of all three were examined and arsenic was found in every one. In one case the vertex and the base were tested separately, and it was discovered that there was quite as much arsenie in the one part as in the other-showing the rnpidity and complete. ness of the diffusion. In a fourth case Witthaus injected the arsenic directly into the stomach and at the emol of five day's he separated from the brain $8.28 \mathrm{mg}$. of arsenic calculated as the trioxid.

In the majority of the foregoing experiments only easily obtainable apparatus was used and the arsenic was injected into that part of the body (the mouth) to which a criminal could have ready nccess. It will also be seen that the amount of arsenic found in the brain after post-mortem injection was greater than that found by Ekeley $(1.2 \mathrm{mrg}$., caleulated as $\mathrm{As}_{2} \mathrm{O}_{3}$, in $1,000 \mathrm{gm}$. of the brain) in the ense reported by him (and referred to in the editorial), in which the arsenic was taken before death.

Walter S. Haines, M.D., Chiengo.

\section{The Insanitary Labor Camp}

To the Editor:-In Tue Journal, May 10, 1913, p. 1464, is an editorial on this subject. While I concur for the most part in the deductions drawn, one statement is so obviously based on incomplete information that, in justice to our own and several other Western states, $I$ call attention to it. The sentence is the following: "Because these camps are controlled by no lnws, and becnuse they are not supervised by any state department, they are a grave menace to the health of the laborers occupying them and the inhabitants of distant as well as adjacent towns."
Reports on industrini camps have been made to the Conference of State and Provincial Boards of IJenlth for each of the past four years. 'The last report, made by myself and lor. T. J). Tuttle of Montana, has not yet been published, but is prictically ready for distribution. This report contains a digest of the laws and regulations controlling industrial camps, us nearly as we could determine them last year. So far an I know, practically all the western provinees of Canada and the states of Montani, Jdnho, Utah, Tonisiana and Washington have done something, at any rate. in attempting to control these camps through their state lourds of henlth. Certain other states, notably Kansas and California, have made some investigations. Therefore it en senreely be said that these eamps are not supervised by any state department.

On pawe ti28 of the Publir Heath Reports of Miarch 28 will be found nepy of our rules and regulations relating to camps. I believe, although I have not the exact date at hand, that the rules of the Louisinn bourd huve been in effect for severid years. The Washington State Board of Health rules have been in effect sine 1910. On page 35 of our last biemnial report will be fomend a lirinf account of the work of this bond on industrial camps, and also in the report of the sanitary inspector, page 312 , is a more detailed refereuce to some camps inspected. In all, this department lus investigated something over 500 indenstrial camples in the last three years and has had exceptionally good sucess in eurying out sanitary improve. ments. The incestigations are fur from what they should be becduse of lack of funds and field foree, but we feel that in no other: line of work lane we aceomplished greater results with the limited funds at ow commund. This subject is rovered more fully in our last conference of state health officials' report, which will soon come from the press.

Bugare R. Kelter, M.D., Senttle, Wash.

Comminsioner, Washington Stite bourd of Health and Bureal of Vitul Statisties.

[Commext--It is shown by our comespondent that several states ure excreising supervision over the sanitation of labor camps. The facts on which our elitorial was based wore drawn chielly from conditions existing in New York. The second sentence, of course, should have read: "Because in many states these eamps are not controlled by any laws and are not supervised by any state department . . ." The danger. to bealth from labor camps is evidently becoming widely recognized.-Wis.]

\section{Suggestion for a Committee to Pass on New Medical Books}

T'o the Editor:-Mny I suggest for the consideration of the American Medical Association at its coming meeting the desirnbility of appointing a committec for the purpose of passing on the intrinsic merits of medieal publications placed on the market?

Publishing louses are financinlly interested in their output, and reviews are ton often written lastily and sometimes perhaps with a personal bias; while no single reviewer asso. cinted with any periodienl cun be expected to possess such encyclopeclic knowledge as is necessary in a field so varied and extensive. For these ressons thousands of plysicians, and especially those far removed from publishing centers, no quite unable to decide what books may be most wortly of their attention.

An advisory or reviewing committec (like the Council on Pharmacy and Chemistry) of cipuble physiciuns, appointed by the Association because of their technical and practicnl knowledge of the various specialties and whose members muy reside in difierent sections of the comntry, could without invidious distinction classify books in such way as to enable purchnsers to make a more sntisfactory sclection than is now possible.

Many of our fraternity cannot afford to purchase largely, and it is often a grent disappointment to discover, when too late, that a poor investment has resulted from an insuflicient knowledge of, or extravagant claims made for, a much needed work. 